\title{
Physical Fitness and Indicators of Cardiovascular Risk in Population with Intellectual Disability
}

\section{Condición física e indicadores de riesgo cardiovascular en población con discapacidad intelectual}

\section{Condição física e indicadores de risco cardiovascular em população com deficiência intelectual}

Diana Alexandra Camargo Rojas, $\mathrm{Mph}^{1 *}$

Marco Aurelio Rodríguez, $\mathrm{Mg}^{2}$

Received: March 27, 2019 - Accepted: September 20, 2019

Doi: https://doi.org/10.12804/revistas.urosario.edu.co/revsalud/a.8736

To quote this article: Camargo Rojas, D. A., \& Rodríguez M. A. (20XX). Physical Fitness and Indicators of Cardiovascular Risk in Population with Intellectual Disability. Rev Cienc Salud. 2020:18(1):10-23. https://doi.org/10.12804/revistas.urosario.edu.co/ revsalud/a.8736

\section{Abstract}

Introduction: This study aimed to determine the relationship between physical condition and indirect indicators of cardiovascular risk in children and young people with intellectual disabilities. Materials and Methods: The study was an observational cross-sectional one, which evaluated the physical condition of 175 students with intellectual disabilities, using the Brockport Physical Fitness battery for children under 18 years of age. For those over 18 years, the same tests were used, but with age scales. For the statistical analysis, normality tests and Pearson correlation were applied with the statistics program SPSS 20.1 version, with $95 \%$ confidence levels. Results: In body composition, a population older than 18 years had higher values than those under 18 years. In children under 18 years of age, a direct correlation was observed between the anthropometric variables, forming a high cardiovascular risk $(\mathrm{r}=0.77 \mathrm{p}$ 0.01); a negative correlation was observed between anthropometric variables with aerobic power and strength $(r=-0.423, r=-0.593 \mathrm{p} 0.01)$. In the population over 18 years of age, there was a negative correlation between arm strength $(r=-0.60 \mathrm{p} 0.01)$ and aerobic power $(r=-0.471 \mathrm{p} 0.01)$ with cardiovascular

1 Research group Cuerpo, Sujeto y Educación. Facultad de Cultura Física, Deporte y Recreación, Universidad Santo Tomás, Bogotá, Colombia.

Corresponding author: diana.camargo@usantotomas.edu.co

2 Facultad de Educación Física, Universidad Pedagógica Nacional, Bogotá, Colombia. 
risk variables. Conclusion: A relationship between the variables of cardiovascular risk and qualities such as strength and aerobic capacity is observed, being physical fitness variables risk predictors.

Keywords: Intellectual disability; physical fitness; risk factors; cardiovascular disease.

\section{Resumen}

Introducción: el objetivo de esta investigación fue determinar la relación entre condición física e indicadores indirectos de riesgo cardiovascular de niños y jóvenes con discapacidad intelectual. Materiales y métodos: estudio observacional de corte transversal, que evalúa la condición física de 175 estudiantes con discapacidad intelectual, utilizando la batería Brockport Physical Fitness para menores de 18 años; para mayores de 18, se utilizaron las mismas pruebas, pero con baremos para su edad. Para el análisis estadístico, se aplicaron pruebas de normalidad y de correlación de Pearson con el programa estadístico SPSS versión 20.1, con niveles de confianza del $95 \%$. Resultados: en la composición corporal, la población mayor de 18 años obtuvo valores más altos que los menores de 18 años. En menores de 18 años, se observó una correlación directa entre las variables antropométricas, configurando un riesgo cardiovascular alto $(\mathrm{r}=$ $0.77 \mathrm{p}=0.01$ ); se observa una correlación negativa entre variables antropométricas con potencia aeróbica y fuerza $(r=-0.423 ; r=-0.593 p=0.01)$. En la población mayor de 18 años, se observó una correlación negativa entre fuerza de brazos $(r=-0.60 p=0.01)$ y potencia aeróbica $(r=-0.471 p=0.01)$, con variables de riesgo cardiovascular. Conclusión: se observa una relación entre las variables de riesgo cardiovascular y cualidades como fuerza y capacidad aeróbica, siendo las de condición física predictoras de un posible riesgo.

Palabras clave: discapacidad intelectual; condición física; factores de riesgo; enfermedad cardiovascular.

\section{Resumo}

Introdução: determinar a relação entre condição física e indicadores de risco cardiovascular de crianças e jovens com deficiência intelectual (DI). Materiais e métodos: estudo observacional de corte transversal, que avalia a condição física de 175 estudantes com deficiência intelectual (DI), utilizando a bateria Brockport Physical Fitness para as pessoas com menos de 18 anos; para as pessoas com mais de 18 anos se utilizaram as mesmas provas, mas com medidas diferentes para sua idade. Para a análise estatística se aplicaram provas de normalidade e de correlação Pearson com o programa estatístico SPSS versão 20.1, com níveis de confiança de $95 \%$. Resultados: em composição corporal, na população com mais de 18 anos obteve valores mais altos que na população mais jovem. Na população com menos de 18 anos, observou-se uma correlação direta entre as variáveis antropométricas, configurando um risco cardiovascular alto ( $\mathrm{r}=0.77 \mathrm{p}$ 0.01); se observa uma correlação negativa entre variáveis antropométricas com potência aeróbica e força $(r=-0.423 ; r=-0.593$ p 0.01). Na população com mais de 18 anos se observou uma correlação negativa entre força de braços ( $r=-0.60$ p 0.01) e potência aeróbica ( $r=-0.471$ p 0.01), com variáveis de risco cardiovascular. Conclusão: observa-se uma relação entre as variáveis de risco cardiovascular e qualidade como força e capacidade aeróbica, sendo variáveis de condição física preditoras de um possível risco.

Palavras-chave: deficiência Intelectual; condição física; fatores de risco; doença cardiovascular.

\section{Introduction}

\footnotetext{
The term intellectual disability (ID) refers to those persons whose intellectual functioning is 1 lower than the population average, characterized by the coexistence of two or more limitations "associated with adaptive areas in communication, home life, social skills, self-management,
} 
health and security” (1). In this sense, according to the American Association on Intellectual and Developmental Disabilities (AAIDD), in 2018, intellectual disability "is a disability characterized by significant limitations in both intellectual functioning (reasoning, learning, problem solving) and in adaptive behavior, which covers many everyday social and practical skills. This disability originates before the age of 18 " (2).

For the purpose of this study, the population of children and youths with DI was approached since it is in condition of disability with barriers to inclusion in different areas of daily life (3), and therefore with high indexes of obesity, thus in risk of acquiring chronic non-communicable diseases ( $\mathrm{CNCD})(4,5)$.

In this way, there is evidence of a notable increase of cardiovascular risk factors due to unhealthy lifestyles in children and youths with ID, since their physical activity is far lower than that of their peers with no disability $(5,6)$. Similarly, the presence of overweight and obesity in population with iD is growing; according to Foley, Harvey, Hae-Ja and So-Yeun, as well as Sherill (1993) and Moreno (2003), quoted by Laureano, "Students in ID condition present high obesity indexes and thus a higher risk of contracting chronic non-communicable diseases (CNCD)" (5).

In adults, certain researches show that there is a higher predisposition to present cardiovascular risk factors in the population with intellectual disability. In this sense, Ojeda and Crespo note in a study conducted in a Chilean population that $49 \%$ of the total sample present overweight or obesity, and $54.3 \%$ showed relative risk related to waist circumference (7). On the other hand, the Spanish Society for the Study of Obesity (SEEDo, for its initials in Spanish) warns that, according to a study of the University of Illinois at Chicago, usA, people with ID present a four-fold risk of developing obesity with a body mass index (BMI) greater than 40, compared with their peers without this condition (8).

On the other hand, regarding physical fitness and cardiovascular risk, some studies, like the one conducted by Secchi, García, España and Piñero, propose establishing a relation between physical condition and indirect cardiovascular risk indicators, such as cardiovascular condition, in children without disabilities (9). In this study they found that $31.6 \%$ of children have a low aerobic capacity, a fact that is indicative of cardiovascular risk. Moreover, in the ID population, Martínez, Ayán, and Cancela found in a study carried out in a Spanish population that "moderate ID was associated with a greater cardiovascular disease risk $(p=0.042)$ "; the latter determined through waist circumference and body mass index as early indicators of cardiovascular risk associated with adiposity (10).

Therefore, it is still necessary to identify the early indicators of cardiovascular risk in the population of children and youths in order to promote health and the prevention of the disease through the practice of physical activity as an effective tool for the prevention of chronic non-communicable diseases. 
In Colombia, assessing the physical condition of school students is a relatively recent aspect in the academic spheres. There are researches that, in the educational field, have taken the initiative to develop studies on this matter, however, the exclusion criteria of these studies include students with any disability, and have focused on the physical fitness of the population of school students with no without disabilities in order to determine standards and to validate assessment batteries $(11,13)$.

Considering these studies, it is evidenced that the physical fitness could be a cardiovascular risk indicator, however, this is not known in the Colombian population with ID. Therefore, the present study seeks to determine the relation between the physical fitness related to health and cardiovascular risk in students with intellectual disability.

\section{Materials and Methods}

This study has a quantitative cross-section, analytical approach. This quantitative approach uses data collection to prove a hypothesis, based on numerical measurement and statistical analysis in order to establish behavior patterns and prove the theory $(14,15)$.

The study was conducted in the Gustavo Restrepo School, D campus, a school with exclusive classroom for ID. The study selected 175 students who met inclusion criteria such as being enrolled in this school for the schoolyear 2016; aged between 15 and 22 years old; having been diagnosed by a physician with an ID such as mild or moderate mental retardation (CIE-10 Classification) or Down syndrome; and having the approval of the parents through an informed consent. Exclusion criteria for the study were not having the parents' or guardians' approval through the signature of the informed consent; having a physical disability associated with a severe musculoskeletal or neurological disorder; and/or presenting medical restriction related to physical activity. This information was provided by the school together with the parents.

For the inclusion of the students as participating subjects, the signature of the informed consent was sought from the parents or legal guardians. Previous to the tests, a meeting with parents and guardians was coordinated in order to explain the research project, as well as its implications and scope. Besides, each participant was asked to present the results of a physical fitness test written by a general physician to detect any restriction for practicing physical activity. Permission to take pictures during the tests was also asked for.

In order to establish relations among variables, the independent variables to be considered were resistance force, flexibility, and cardiopulmonary performance, included in the fitness conditions for health. The variables related to body composition (body fat percentage, waist circumference, body mass index), considered as early indicators of cardiovascular risk and associated with adiposity, were established as dependent variables. 
Considering the precedents presented before, confusion variables for the descriptive analyses included age, gender and type of disability; for the correlation analysis, the confusion variable was age.

For the present study, the variables included in the physical fitness for health: resistance force, flexibility, cardiopulmonary performance, and body composition, were assessed. Specifically, for the body composition variable following measuring tests were conducted: calculation of body weight and body fat, with impedance scale $(\mathrm{r}=0.88-0.89$; $95 \% \mathrm{cI}=0.95)(16,17)$; height measurement, with measuring rod; and body mass index and waist circumference, with tape measure (in females: sensitivity $82.35 \%$, specificity 78.77 ; in males: sensitivity $82.03 \%$, specificity $94.83 \%$ ); for assessing flexibility of the posterior trunk and lower limbs, the Sit and Reach protocol proposed by Winnick and Short was used; resistance was measured with the Curl Up Test (cci 0.095, R = 0.93-0.97) $(16,17)$, Extended Arm Hang Test (alpha $=0.85$ in population with mental retardation), and prehensile dynamometer (construct validity: Winnick and Short) $(16,17)$; cardiopulmonary performance was assessed with the Course Navette Test and PACER (alpha $=0.97$ in population with mental retardation) $(16,17)$.

The Brockport Physical Fitness Test and the corresponding scales, a battery proposed by Joseph P. Winnick in 1999 for children and youths between 10 and 17 with disabilities, which was updated in 2014, was applied in children under 18 years of age. For the population older than 18 years, the protocols and scales of the American College of Sports Medicine were used; and for measuring body mass index, the wHo scales. In the Course Navette and PACER tests, the Leger et al. equation $(16,17)$ was used, for children younger than 19 years: $\mathrm{VO}_{2} \mathrm{Max}=31.025+$ $(3.238 \times$ S $)-(3.248 \times A)+(0.153 \times$ S x A); and for youths older than 19 years: $5.857 \times$ S - 19.458 (18).

The selection bias was minimized since all students had the possibility of participating in the research, meeting all inclusion and exclusion criteria described before.

In order to reduce and prevent measurement bias, training on the selected tests was provided to the persons who carried out the measurements. The researchers performed the measurements to prevent data manipulation and management.

In order to conduct the analyses, data were grouped by age, gender and diagnosis. This way, descriptive analyses were performed in youths younger and older than 18 years independently, as well as comparisons between males and females. Likewise, descriptive analyses by diagnosis were carried out considering the differential behavior put forward in literature between mental retardation and Down syndrome. Correlation analyses were performed in two groups, participants younger than 18 years and older than 18 years, taking into account that the data tests, scales and behaviors were different.

Data were registered in an Excel database that was exported to the SPSS version 20.1 program aiming at performing the respective multivariate and bivariate analyses with descriptive and analytical statistics. For the normality analysis, the Kolmogorov-Smirnov test, with 
a confidence level of $95 \%$, was implemented. Measures of central tendency such as standard average and deviation were conducted for those continuous variables with normal behavior. Likewise, for correlations the Pearson correlation coefficient was used. The Spearman correlation coefficient, $\rho$ (rho), a measure for the correlation between two aleatory variables was used for those variables not presenting a normal behavior.

This research complies with the postulates of the Declaration of Helsinki and the Resolution 8430 of 1993 relating to clinical researches in Colombia, since it is a moderate-risk research because the carried out interventions can change the baseline physiological conditions of these specific subjects $(19,20)$. For this reason, the study was not performed in the population with medical contraindication for the practice of physical activity, or with any baseline pathology that could be affected with the implementation of the tests. Likewise, considering the Resolution 8430, an informed consent of the parents and guardians authorizing the participation or non-participation of their children was applied, moreover, an informed approval of each student was also implemented. The latter was reviewed by the psychosocial staff of the school the participating children and youths attend. This project had also the approval of the Advisory Committee of the Masters' Degree in Physical Education for Health of the University of Santo Tomás, in charge of approving the projects and ensuring the fulfilment of the ethical principles. By the time the project was conducted, the University did not have an ethics committee.

\section{Results}

ne of the relevant findings shows the difference found in the contrasting results of males and females, warning that females have a poorer physical fitness with cardiovascular risk levels - this assessed with indirect indicators such as body mass index (вмI) and body fat percentage-greater than in males, particularly in the population older than 18 years. However, there are exceptions among males that alerts of a greater cardiovascular risk in some of them (figure 1, figure 2). 

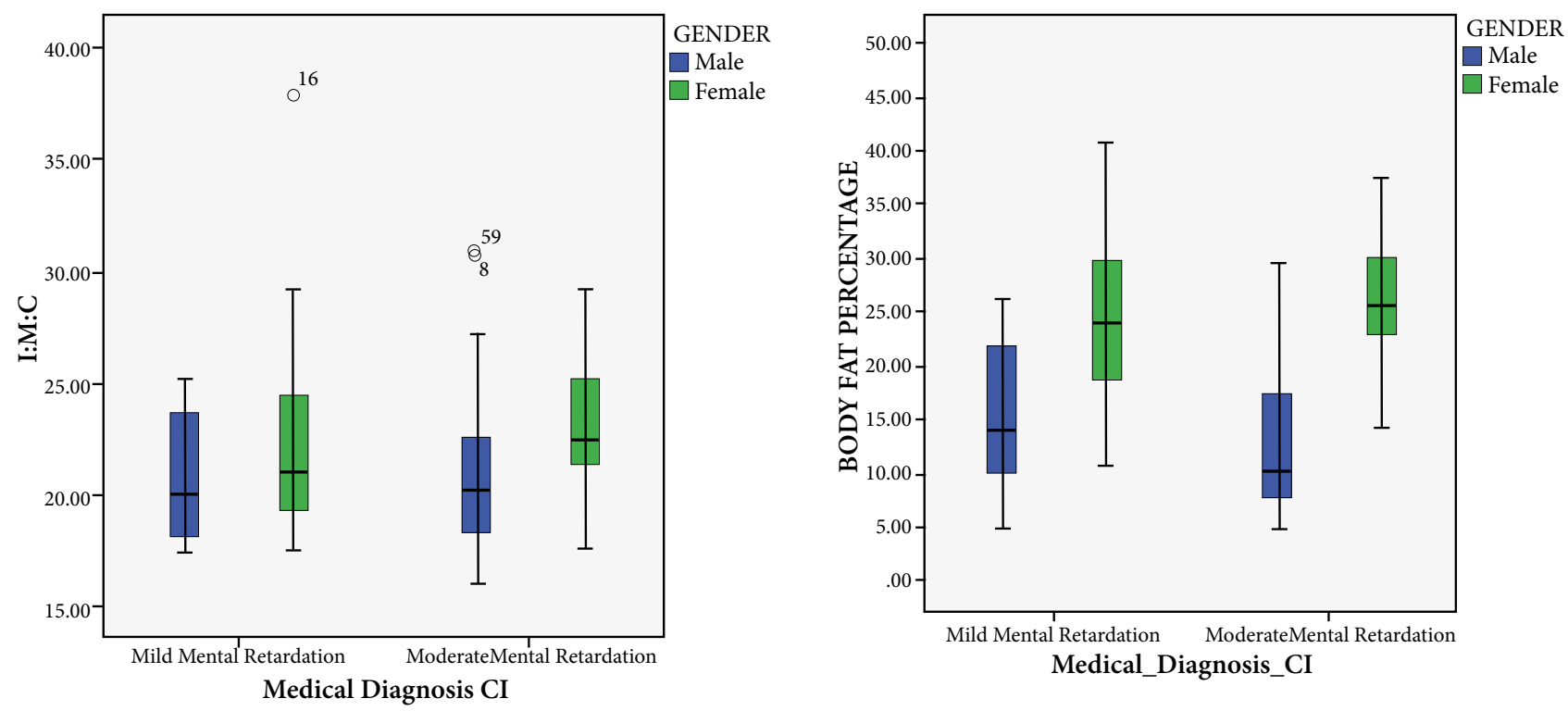

Figure 1. BMI and body fat percentage through medical diagnosis, grouped by gender, younger than 18 years old

Source: The authors. Retrieved from the Master's dissertation conducted by Marco Aurelio Rodríguez in the 2016 Master's Degree Program in Physical Activity for Health, University of Santo Tomás, available in: https://repository.usta.edu.co/bitstream/handle/11634/4147/Rodriguezmarco2016.pdf?sequence=1\&isAllowed=y
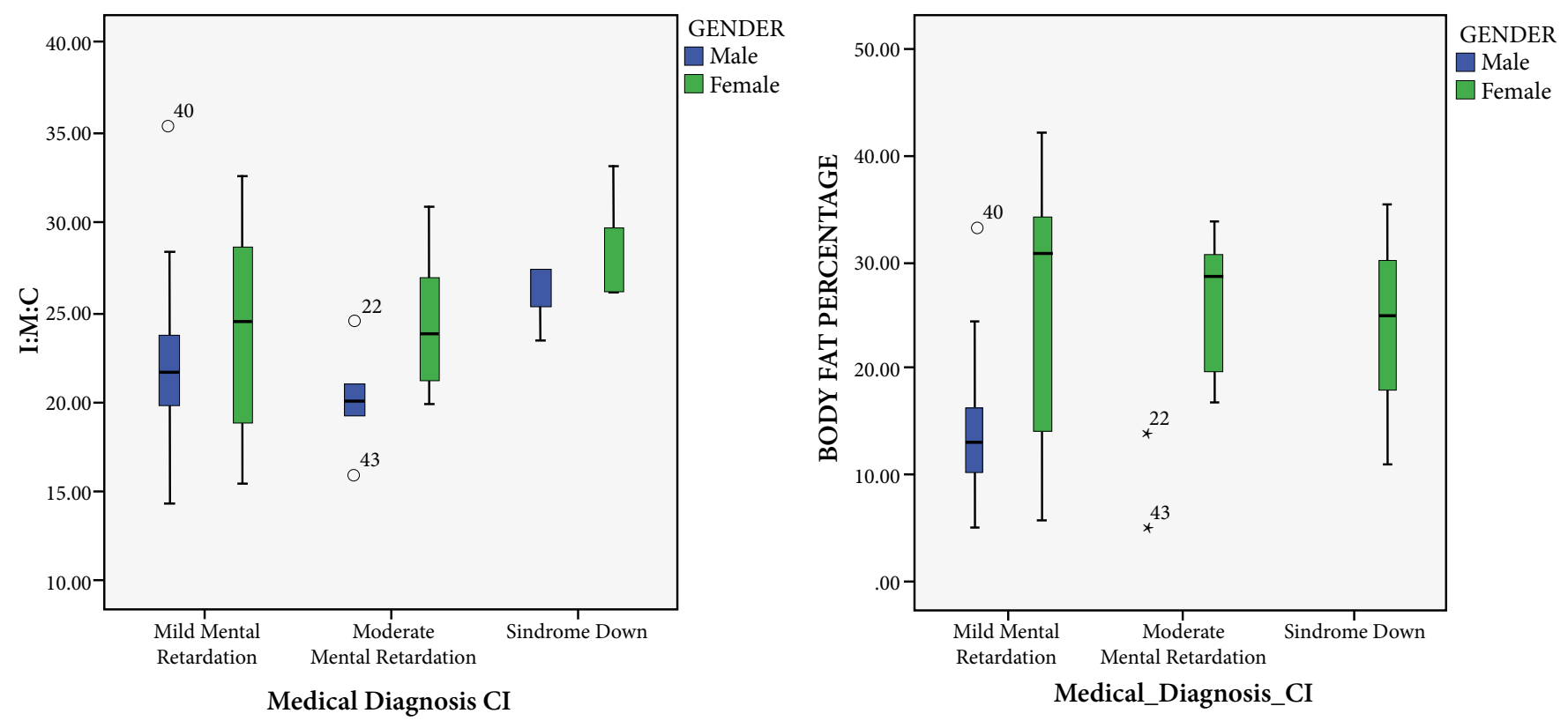

Figure 2. Body fat percentage and BMI through medical diagnosis, grouped by gender, in people older than 18 years

Source: The authors. Retrieved from the Master's dissertation conducted by Marco Aurelio Rodríguez in the 2016 Master's Degree Program in Physical Activity for Health, University of Santo Tomás: https://repository.usta.edu.co/bitstream/handle/11634/4147/ Rodriguezmarco2016.pdf? sequence=1\&isAllowed=y

Regarding some physical fitness variables, such as cardiopulmonary resistance in the population younger than 18 years, the results were lower in females compared to those in males, constituting a higher cardiovascular risk in this population (figure 3). 


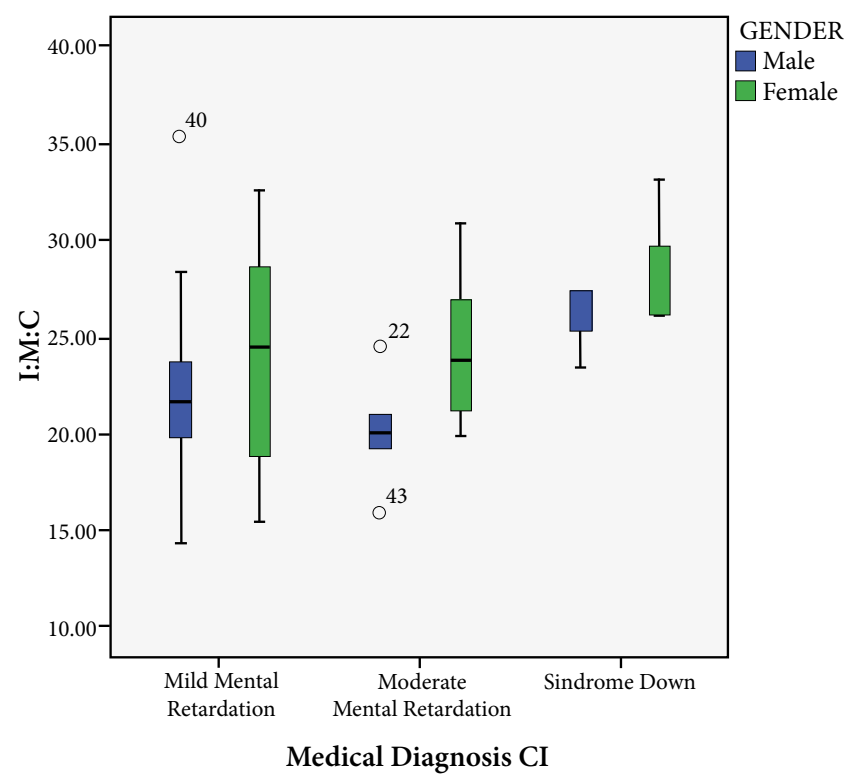

A

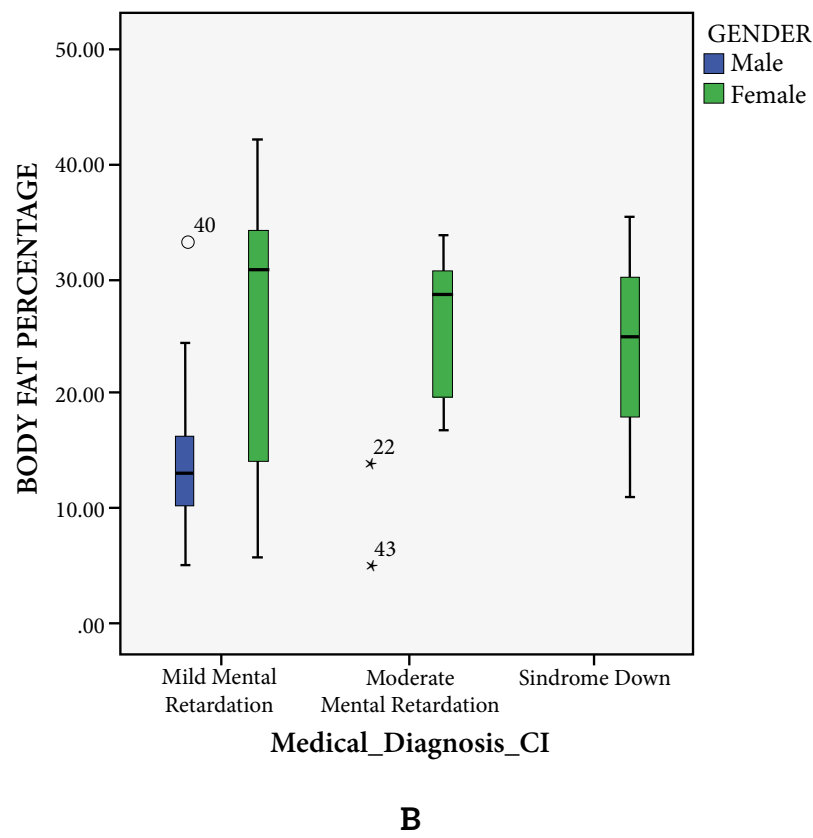

Figure 3. $\mathrm{VO}_{2}$ Máx. ml.min.Kg and medical diagnosis, grouped by gender

\section{A. People aged under 18 years; B. People aged above 18 years. Source: The authors.}

Retrieved from the Master's dissertation conducted by Marco Aurelio Rodríguez in the 2016 Master's Degree Program in Physical Activity for Health, University of Santo Tomás: https://repository.usta.edu.co/bitstream/handle/11634/4147/Rodriguezmarco2016. pdf?sequence=1\&isAllowed $=y$

In population older than 18 years a third diagnosis comes up, Down syndrome (DS), which was not present in the population aged under 18 years. In this population cardiovascular risk is higher in those diagnosed with Ds, since it is clear that their physical fitness shows poor and low results, while the anthropometric variables lie over the overweight and obesity levels, determined based on waist circumference, body fat percentage and BMI. Body fat percentage for males in general are found in normal valuation ranges, even though there are differences by diagnosis, showing a higher percentage in those diagnosed with Ds. By contrast, females register high, and obesity values, higher than in females diagnosed with mild ID (figure 2).

As to the cardiopulmonary condition in population older than 18 years, behavior was rated fair standar and low. In the population with Ds, values for percentile 50 show a low physical fitness, slightly higher in some females who reach a fair standar condition. In the population diagnosed with moderate iD, the difference between males and females is considerably higher for males, since the mean reaches a good, and in some case excellent physical assessment; the opposite in females, whose 50 percentile lies in a standar and downward physical assessment. For the population diagnosed with mild ID, behavior is similar, but 50 percentile of males and females does not exceed that of the population diagnosed with moderate ID.

Once the data was collected based on the assessed variables, the research clearly shows the low levels of physical fitness of the students with intellectual disability in the Gustavo Restrepo 
School, allowing to establish in an indirect fashion cardiovascular risk. However, considering the variables defined as cardiovascular risk predictors, following results are evidenced:

As to the relations between the physical fitness variables and the indirect variables with cardiovascular risk associated with adiposity, a significative and inversely proportional correlation between body fat percentage and force of the upper limbs $(r=0.593, p=0.01)$ was found; as it is between body fat percentage and abdominal strength $(r=0.27, p=0.01)$; as well as with aerobic capacity $(-0.423, \mathrm{p}=0.01)$. In this population, waist circumference and вмг did not present any correlation with the physical fitness variables, where the body fat percentage could be considered the main risk predictor (table 1).

Table 1. Correlation between anthropometric (cardiovascular risk) and physical fitness variables in youths younger than 18 years old.

\begin{tabular}{llccc}
\hline & BMI & $\begin{array}{c}\text { Body Fat } \\
\text { Percentage }\end{array}$ & $\begin{array}{c}\text { Waist } \\
\text { Circumference }\end{array}$ \\
\hline VO $\mathbf{F}_{2}$ Max & Pearson Correlation & $-250^{*}$ & $-.423^{* *}$ & -.245 \\
Abdominal & Sig (Bilateral) & .048 & .001 & .053 \\
Strengh & Searson Correlation & -.027 & $-.272^{*}$ &.- .20 \\
Arm & Pearson Correlation & $-.365^{* *}$ & .031 & .878 \\
Strength & Sig (Bilateral) & .003 & $-.593^{* *}$ & -.240 \\
\hline
\end{tabular}

\section{${ }^{*}$ Correlation is significant at 0.05 level}

${ }^{* *}$ Correlation is significant at 0.01 level

Source: Master's dissertation conducted by Marco Aurelio Rodríguez in the 2016 Master's Degree Program in Physical Activity for Health, University of Santo Tomás, available in: https://repository.usta.edu.co/bitstream/handle/11634/4147/Rodriguezmarco2016. pdf?sequence=1\&isAllowed $=y$

Regarding the correlations of the population older than 18 years, a high correlation $(\mathrm{r}=0.78, \mathrm{p}=0.01)$ among the anthropometric variables, specifically among вмI, body fat percentage and waist circumference was observed, thus being in this case the waist circumference a fundamental risk indicator, in contrast to the population younger than 18 years. Considering the relations between the physical fitness variables and the indirect variables with cardiovascular risk associated with adiposity, findings show a significant and inversely proportional correlation between body fat percentage and the force of the upper limbs $(\mathrm{r}=0.592, \mathrm{p}=0.01)$; BмI and the force of the upper limbs $(\mathrm{r}=0.605, \mathrm{p}=0.01)$; between BMI and abdominal strength $(r=0.28, p=0.05)$; as well as between body fat percentage and aerobic capacity $(r=-0.471, p=0.01)($ table 2$)$. 
Table 2. Correlation between anthropometric (cardiovascular risk) and physical fitness variables in youth older than 18 years

\begin{tabular}{llccc}
\hline & BMI & $\begin{array}{c}\text { Body Fat } \\
\text { Percentage }\end{array}$ & $\begin{array}{c}\text { Waist } \\
\text { Circumference }\end{array}$ \\
\hline VO $_{2}$ Max & Pearson Correlation & $-.428^{* *}$ & $-.471^{* *}$ & $-.380^{* *}$ \\
& Sig (Bilateral) & .001 & .000 & .005 \\
Abdominal & Pearson Correlation & $-.258^{*}$ & -.262 & -.172 \\
Strengh & Sig (Bilateral) & .037 & .055 & .213 \\
Arm & Pearson Correlation & $-.605^{* *}$ & $-.592^{* *}$ & $-.560^{* *}$ \\
Strength & Sig (Bilateral) & .000 & .000 & .000 \\
\hline
\end{tabular}

${ }^{*}$ Correlation is significant at 0.05 level

${ }^{* *}$ Correlation is significant at 0.01 level

Source: Retrieved from the Master's dissertation conducted by Marco Aurelio Rodríguez in the 2016 Master's Degree Program in Physical Activity for Health, University of Santo Tomás, available in: https://repository.usta.edu.co/bitstream/handle/11634/4147/ Rodriguezmarco2016.pdf? sequence $=1$ \&isAllowed $=\mathrm{y}^{*}$ Correlation is significant at 0.05 level

\section{Discussion}

$\mathrm{T}$

The study allowed the comparison of the behavior of physical fitness by gender, age, and intellectual disability level, which showed a relation between physical fitness and the cardiovascular risk indirect indicators of the assessed students. Thus proving the hypothesis advanced here since the same findings showed that those students with greater waist circumference, higher body fat percentage and higher BMI, with values between overweight and obesity, presented lower $\mathrm{VO}_{2} \mathrm{Max}$ and in the same way, lower strength of the arms. These findings were similar to those presented by Secchi, García, et al., who established that the population with intellectual disability present cardiovascular risk, determined based on the early indicators related to cardiopulmonary resistance (9). Likewise, relations between arms strength and early indicators of cardiovascular risk associated with adiposity have been found in the Colombian pediatric population without disability in the studies conducted by Rodríguez, et al., who found that "the best muscle performance was associated with better indicators of physical well-being” (21). They also affirm that "the assessment of muscle strength in early ages will allow the implementation of programs for cardiovascular and metabolic risk prevention”, considering the power of an early risk predictor.

The difference between the population younger than 18 years and that older than 18 is also noticeable, since the minors show a better physical fitness and anthropometric values somehow apart from cardiovascular risk in the older population. With good, and sometimes excellent results for the $\mathrm{VO}_{2} \mathrm{Max}$ and strength values, corroborating that in the ID population cardiovascular risk grows over the years in relation to the assessment of physical fitness and anthropometric condition, as Wouters, et al., put it, thus making them particularly vulnerable to health problems in adulthood (22). 
One of the first conclusions of this research is having proved that it is possible to include populations with mild and moderate ID and persons with DS in studies related to assessing physical fitness using reliable and internationally valid tests. This allowed evidencing the actual difference in terms of physical fitness in population with mild to moderate intellectual disability or Down syndrome. These findings are similar to those established by Martínez et al., who found in their study performed in a Spanish population that "moderate iD has been associated with a higher risk of cardiovascular disease $(p=0.042)$ ", the latter determined by measuring waist circumference and вмг as early indicators of cardiovascular risk associated with adiposity and also used in the present study (10). Likewise, Golubovic et al., obtained in their study significantly low results of the physical fitness performance in children with intellectual disability compared to typically developing children (23).

On the other hand, similarities with studies performed in population with iD in other countries focused on assessing physical fitness associated with health were found, thus corroborating that overweight and obesity have become a problem of public health that are also present in the ID population, not only in developed countries, it is also increasing in Latin America and, of course, in Colombia, as it was evidenced in this study $(4,8,22)$.

Considering the correlation of gender, physical activity and body composition, the study showed that physical fitness in males presents higher values both for children younger than 18 years and for youths older than 18 years, thus proving that for them, the assertion that in this population there is lower participation in physical activity is maintained, not forgetting the case of some male subjects who show extreme high values of cardiovascular risk. In females, the $\mathrm{VO}_{2} \mathrm{Max}$ shows warning values since in the 50 percentile in females it has low levels, as it does in males with Ds (24-26). As to body composition, females show values nearing cardiovascular risk figures in a higher proportion than in males, and even further nearer to this risk in the Ds population.

Finally, it is worth mentioning that "there is consensus that the measure of waist circumference (wc) is an indirect indicator of the presence of intra-abdominal fat. This assessment is easily available and low cost, for this reason it is used to early predict the risk of suffering diseases such as diabetes mellitus, hypertension and cardiovascular conditions” (27). However, in the present study this variable is not considered a risk indicator for the population aged under 18 years, to whom it would be relevant to measure blood pressure, body fat and strength percentages, as Rodríguez et al. suggest (21).

Generally speaking, it can be asserted that in persons with iD there is an inversely proportional correlation between age and physical fitness, since it was found that these variables decreased with increasing age and show lower percentiles in the individuals diagnosed with Down syndrome (sD).

This research reveals the physical fitness of students with ID attending the Colegio Gustavo Restrepo, by using anthropometric and physical fitness variables that reflect the inversely 
proportional correlation between the physical fitness variables and the early cardiovascular risk indicators related to adiposity. Likewise, this research opens the door toward the possibility of future studies in this population since this population has been excluded in previous studies in Colombia related to assessing physical fitness in school students.

\section{Limitations of the Study}

ven though the study was conducted within the universe of this particular educational Einstitution, the results cannot be generalized to the population with similar characteristics, school children or youths with mild and moderate intellectual disability.

\section{Author's Contribution}

$\mathrm{M}$ arco Aurelio performed data recollection and analyzed the information obtained from the analysis for the discussion. Diana Camargo Rojas analyzed the information and worked in the discussion and writing process of the article following the STROBE methodology.

\section{Acknowledgements}

$\mathrm{W}$ e are especially grateful to the students and parents of the Colegio Gustavo Restrepo, D building, as well as to the Masters' Degree in Physical Education for Health of the Universidad de Santo Tomás. ${ }^{3}$

\section{Conflict of Interests}

Non declared.

3 The present publication resumes the masters' thesis written by Marco Aurelio Rodríguez in 2016 in the Master in Physical Activity for Health in the University of Santo Tomás, that can be retrieved from: https://repository.usta.edu.co/bitstream/handle/11634/4147/Rodriguezmarco2016. pdf? sequence=1\&isAllowed $=y$ 


\section{References}

1. Pié A, Duch R, Martínez M, Miró R, Rodríguez I. Diversidad(es). Discapacidad, altas capacidades intelectuales y trastornos del espectro autista. Spain: Editorial UOC, S.L.;2014.

2. American Association on Intellectual and Developmental Disabilities (AAIDD). Intelectual desability. AIDD [Internet]. 2018 [cited 2019 dec 8]. Available from: https://aaidd.org/ intellectual-disability/definition/faqs-on-intellectual-disability\#.WzO0WRJKjnU

3. Moreno M. Políticas y concepciones en discapacidad: Un binomio por explorar [Internet]. 1st ed. Bogota: Universidad Nacional de Colombia; 2007 [cited 2019 dec 8]. Available from: http://www.bdigital.unal.edu.co/4586/1/9789587017762.pdf

4. Foley JT., Harvey S., Hae-Ja C, So-Yeun, K. The Relationships among Fundamental Motor Skills, Health-Related Physical Fitness, and Body Fatness in South Korean Adolescents with Mental Retardation. Res Q Exerc Sport. 2008; 79(2): 149-157. Doi: 10.1080/02701367.2008.10599478

5. Laureano, E. Estado de la situación de la aptitud física en niños y niñas con discapacidad intelectual en edades escolares [Internet]. Tesis de maestría en Educación. Universidad Metropolitana. 2010 [cited 2019 dec 8]. Available from: http://repositoriocdpd.net:8080/ bitstream/handle/123456789/444/Tes_LaureanoOrtizE_EstadoSituacionAptitud_2010. pdf?sequence $=1$

6. Collins K, Staples K. The Role of Physical Activity in Improving Physical Fitness in Children with Intellectual and Developmental Disabilities. Res Dev Disabil. 2017;69:4960. Doi: $10.1016 /$ j.ridd.2017.07.020

7. Ojeda R, Crespo M. Correlación entre el índice de masa corporal y la circunferencia de cintura en una muestra de niños, adolescentes y adultos con discapacidad, de Temuco, Chile. Inter J Morphol. 2011; 29(4): 1326-1330. Doi: 10.4067/S0717-95022011000400043

8. Sociedad Española para el Estudio de la Obesidad (SEEDO). La SEEDo alerta de la alta prevalencia de obesidad entre las personas con discapacidad intelectual [Internet]. SEEDO; 2014 [cited 2019 dec 8]. Available from: https://www.seedo.es/images/site/Obesidad_y_ discapacidad_intelectual_04_14.pdf

9. Secchi J; García G; España V, Castro J. Condición física y riesgo cardiovascular futuro en niños y adolescentes argentinos: una introducción de la batería ALPHA. Arch Argent Pediatr; 2014; 112(2):132-140. Doi: 10.5546/aap.2014.132

10. Martínez R, Ayán C, Cancela J. Condición física saludable y riesgo cardiovascular en jóvenes con discapacidad intelectual. Cartas al editor. Salud Pública Mex. 2015; 57(3): 192-193.

11. Fernández J, Hoyos L. Perfil de las cualidades físicas y antropométricas de los escolares colombianos. Bogotá: Universidad Pedagógica Nacional. 2007

12. Santamaría JI, Estrada P, Sepúlveda M, Hernández H, Suarez J. Capacidades físico-motrices y perfil antropométrico de escolares entre 7 y 11 años de la básica primaria de la Institución Educativa Rafael Mejía de Sabaneta (Colombia). Educación Física y Deporte. 2013 32(1): 1173-1184. 
13. Fernández J. Estudio transversal de las cualidades funcionales de los escolares bogotanos: Valores de potencia aeróbica, potencia muscular, velocidad de desplazamiento y velocidad de reacción, de los 7 a los 18 años Educación Física y Deporte. 2013; 32(1):1151-1170.

14. Hernández R, Fernández C, Baptista M. Metodología de la investigación. 6th ed. México D. F: McGraw-Hill; 2014.

15. Sierra R. Técnicas de investigación social. Teoría y Ejercicios. 9th ed. Paraninfo. 1997.

16. Winnick J, Short F. The Brockport Physical Fitness Test Manual. A Health-Related Test for Youths with Physical and Mental Disabilities. $1^{\text {st }}$ ed. Brockport: State University of New York College; 1999.

17. Winnick J, Short F. The Brockport Physical Fitness Test Manual: A Health - Related assessment for youngsters with Disabilities. $2^{\text {nd }}$ Edition. Brockport: State University of New York College. 2014.

18. García J. Bases Teóricas de entrenamiento: (principios y aplicaciones). Madrid: Madrid Gymnos. 1996.

19. Asociación Médica Mundial. Declaración de Helsinki, 2013.

20. Colombia, Congreso de la República. Resolución 8430 de 1993, Ministerio de Salud (2013 oct 4). Available from: https://www.minsalud.gov.co/sites/rid/Lists/BibliotecaDigital/RIDE/ DE/DIJ/RESOLUCION-8430-DE-1993.PDF

21. Rodríguez F, Gualteros J, Torres J, Umbarila L, Ramírez, R. Asociación entre el desempeño muscular y el bienestar físico en niños y adolescentes de Bogotá, Colombia. Nut Hosp. 2015; 32(4): 1559-1566. Doi:10.3305/nh.2015.32.4.9310

22. Wouters M, Evenhuis H, Hilgenkamp T. Systematic Review of Field-Based Physical Fitness Tests for Children and Adolescents with Intellectual Disabilities. Res Dev Disabil. 2017; 61: 77-94.

23. Golubovic S, Maksimovic J, Golubovic B, Glumbic N. Effects of Exercise on Physical Fitness in Children with Intellectual Disability. Res Dev Disabil. 2012; 33(2): 608-614. Doi: 10.1016/j.ridd.2011.11.003

24. Hormiga C. Influencia del género en la práctica regular de actividad física en Santander, Colombia [Internet]. Tesis presentada como requisito parcial para optar al título de Doctora en Salud Pública. Universidad Nacional de Colombia. 2015 [cited 2019 dec 8]. Available from: http://bdigital.unal.edu.co/52823/1/37726849.2016.pdf

25. Valis J and González M. Physical Activity Differences for College Students with Disabilities. Disabil Health J. 2017; 10(1): 87-92. Doi: 10.1016/j.dhjo.2016.09.003

26. Harrisa L, McGartya A, Hilgenkampb T, Mitchellc F, Melville C. Correlates of Objectively Measured Sedentary Time in Adults with Intellectual Disabilities. Prev Med Reports. 2018; 9: 12- 17. Doi: 10.1016/j.pmedr.2017.11.010

27. Aráuz A, Guzmán S, Roselló M. La circunferencia abdominal como indicador de riesgo de enfermedad cardiovascular. AMC. 2013; 55(3): 122-127. 